Cite as: Howard, G. R., Lubbe, S., \& Klopper, R. (2015). Green IS: Enabling, transforming, both, or neither? Proceedings of Informing Science \& IT Education Conference (InSITE) 2015, 231-245. Retrieved from

http://Proceedings.InformingScience.org/InSITE2015/InSITE15p231-245Howard1521.pdf

\title{
Green IS: Enabling, Transforming, Both, or Neither?
}

\author{
Grant R. Howard \\ University of South Africa (UNISA), Florida, \\ Gauteng, South Africa \\ howargr@unisa.ac.za
}

Sam Lubbe

University of Zululand, KwaDlangezwa, KwaZulu-Natal, South Africa

lubbes@unizulu.ac.za

\section{Rembrandt Klopper University of KwaZulu-Natal, KwaZulu-Natal, South Africa rembrandtklopper@icloud.com}

\begin{abstract} tudinous environmental sustainability scenarios.

Material published as part of this publication, either on-line or in print, is copyrighted by the Informing Science Institute. Permission to make digital or paper copy of part or all of these works for personal or classroom use is granted without fee provided that the copies are not made or distributed for profit or commercial advantage AND that copies 1) bear this notice in full and 2) give the full citation on the first page. It is permissible to abstract these works so long as credit is given. To copy in all other cases or to republish or to post on a server or to redistribute to lists requires specific permission and payment of a fee. Contact Publisher@InformingScience.org to request redistribution permission.
\end{abstract}

The problem addressed in this paper is the ambiguity that exists in the usage of the terms "enable" and "transform" and their related forms in the Green IS literature. This ambiguity creates uncertainty, both conceptual and practical, about the precise role of Green IS in these research and use contexts. Consequently, the exact relationship between Green IS and environmental sustainability can be obscured. The objective then was to disambiguate these terms and their related forms by defining them independently from the Green IS literature, and subsequently using those independent meanings to content analyze their use in the top journals in the IS field. The results provided evidence that the enabling role was far more prominent than the transforming role. Nevertheless, while distinct, both roles are are equally significant and valuable for environmental sustainability. However, based on the relative frequencies, the enabling role of Green IS provides more frequent environmental sustainability returns. Thus, it may be preferable for Green IS research to focus on exposing the enabling capabilities of Green IS for optimal success in the multi-
Keywords: Enabling, Environmental sustainability, Green computing, Green Information Systems (Green IS), Green Information Technology (Green IT), Transforming.

\section{Introduction}

Given the global imperative for environmental sustainability (ES), Green Information Systems (IS) research is an 
important and pertinent research domain. The prominent calls for this research (Melville, 2010; Watson, Boudreau, \& Chen, 2010; Malhotra, Melville, \& Watson, 2013) and similar research motivations have resulted in an array of theoretical and empirical research involving Green IS at various levels of analysis; as exemplified in Appendix B.

Two emergent and important roles played by Green IS are the enabling role and transforming role. Indeed, both roles have resulted in the achievement of vital aspects of ES, which is the ultimate goal and measure of Green IS. Thus, both roles are equally significant and valuable, although distinct. Each role has consequences for future research and practice, and ES: Where one role provides more frequent ES returns, it may be beneficial to focus on that role to optimize ES efforts.

The problem addressed in this paper is the ambiguity that exists in the usage of the terms "enable" and "transform" and their related forms in the Green IS literature. This ambiguity creates uncertainty, both conceptual and practical, about the precise role of Green IS in these research and use contexts. Consequently, the exact relationship between Green IS and ES can be obscured. Addressing this problem is important and useful because these terms are conceptual handles on the role of Green IS in theory and in practice.

Two examples of such ambiguity are the phrases "IS-enabled sustainability transformation" (Seidel, Recker, \& Vom Brocke, 2013) and "IT-enabled business transformation" (Elliot, 2011). The author contends that these phrases contain ambiguity: Are the transformations a direct result of IS/IT or are they a direct result of other factors and only enabled by IS/IT or is there some combination of IS/IT transforming and enabling?

Another form of ambiguity occurs when the terms "enable" and "transform" and their related forms are used to propose high-level research agendas. For example, “... we need to demonstrate how the transformative power of IS can be leveraged to create an ecologically sustainable society" (Watson et al., 2010), and "Our tentative research agenda for information systems and environmental sustainability focuses on informing beliefs, enabling actions, and transforming outcomes" (Melville, 2010). The agenda to transform for ES is clear but the exact nature of the roles played by IS are not explicit.

The objective then is to disambiguate these terms and their related forms by defining them independently from the Green IS literature, and subsequently using those independent meanings to content analyze their use in the top journals in the IS field.

The research questions are:

1. How are the terms "enable" and "transform" and their related forms used in the Green IS literature?

2. What does the usage reveal about the role of Green IS and their relationship with ES?

3. What consequences does the usage have for the field?

The terminology analysis section follows this introduction and develops the definitions of the terms independently from the Green IS literature. Following the terminology analysis is the research method section where content analysis is explained and justified, and the sampling and coding dictionary is exposed. Thereafter, the findings section presents the discovered journal articles, the concept contingency table resulting from the content analysis, and the subsequent analysis and findings. The paper ends with concluding remarks, which clarify the roles of Green IS in the literature. 


\section{Terminology Analysis}

In order to define these two terms authoritatively and independently, two online dictionaries were referred to, namely Dictionary.com (Dictionary.Com. n.d.) and Oxford Dictionaries (Oxford Dictionaries. n.d.). The use of two dictionaries enhances confidence in the application of meaning. Both these dictionaries were selected due to their authority, reliability, integrity, and online accessibility. They were both listed on RefSeek's guide to the 30 best online dictionaries, thesauri, and definition aggregators (Refseek.Com, n.d.). In addition, at the time of their use Oxford Dictionaries were published by Oxford University Press, which was a department of the University of Oxford.

The dictionaries indicated that the verb "enable" means to provide the means for something. Thus, where there is an outcome and Green IS enable that outcome, then those Green IS provided the means for achieving that outcome. Those Green IS can be regarded as the instrument or mechanism for accomplishing that outcome. In addition, there is the implication that without those Green IS that outcome could not be accomplished because only Green IS enable that outcome.

In contrast, the dictionaries indicated that the verb "transform" means to alter radically in form or to make a marked change in form. Thus, where Green IS transform a scenario of interest, then those Green IS alter radically that scenario. Furthermore, the adverb "radically" indicates that those Green IS have altered or changed the scenario drastically, fundamentally, and in a nontrivial way.

Additionally, the noun form of the verb "transform" has been used, namely transformation. A transformation is a special type of change; it is a drastic, fundamental, and non-trivial change. Where a transformation has occurred then the scenario of interest has been altered or changed drastically or fundamentally from its initial state. However, determining whether a change is a transformation or not, is essentially a subjective exercise, requiring judgment and a consideration of the specific context (Lucas Jr., Agarwal, El Sawy, \& Weber, 2013).

A useful distinction between the two terms, "enable" and "transform", is their comparative activeness or passiveness and the resultant degree of change. The term "enable" suggests a comparatively passive or even indirect role, where Green IS only facilitate a change and the resultant degree of change can vary from negligible to extreme. However, the term "transform" suggests a comparatively active or direct role where Green IS produce, cause, or drive the change, and the resultant degree of change is extreme only.

Furthermore, a combination of the terms "enable" and "transform" has been used, for instance "IS-enabled transformation". Here the past participle form of the verb "enable" is joined to the noun "IS" by a hyphen to produce a compound adjective that describes the other noun "transformation". This phase does not clarify whether the transformation is produced, caused, or driven by Green IS; or by other factors and just enabled by Green IS. For example, the transformation may be driven by legislation and only facilitated by Green IS, in other words, legislation is transforming the scenario and Green IS are enabling that transformation. A potential solution may be the use of compound adjectives other than IS-enabled to describe the noun "transformation", such as IS-driven, IS-induced, or IS-facilitated. These provide better clarity as to the specific nature of the transformation and its relationship with IS.

Indeed, it can be argued that there is a close and complementary conceptual relationship between the terms "enable" and "transform" when IS are involved in some change scenario. For instance, when IS provide the means for or enable a change, then it may be argued that once those IS are introduced into the scenario then those IS have also caused the scenario to have altered radically or transformed. Thus, IS are enabling and transforming. Similarly, when IS cause or drive a radi- 
cal change or transform a scenario, then it may be argued that those IS have also provided the means for or enabled that radical change. Again, IS are transforming and enabling. However, such arguments may obscure the predominant role played by the IS in those scenarios and consequently research and practice effectiveness.

Importantly, Green IS that enable and Green IS that transform can be equally valuable for theory and practice. It may be that Green IS enable a vital ES transformation and, equally, it may be that Green IS cause or drive a vital ES transformation. In both cases Green IS have made a vital contribution, although a distinct contribution. Thus, the distinction is not one about importance or value it is instead one of definition and clarity to inform research and practice. This section provided the terminology analysis of the terms under consideration. The next section presents the research method applied, being content analysis, for answering the research questions.

\section{Research Method}

\section{Content Analysis}

Content analysis has been successfully used to analyze texts in IS research (Loeser, 2013; Siponen \& Vance, 2010; Bhattacherjee \& Premkumar, 2004) and is valuable for facilitating theory elaboration (Ceci \& Iubatti, 2012). Content analysis aims to quantify textual content objectively in terms of predetermined categories in a replicable and systematic manner (Bryman \& Bell, 2011; Ceci \& Iubatti, 2012). Its objectivity lies in its procedural transparency for assigning data to category codes. Moreover, it is systematic in its application of consistently applied rules and it is replicable as any researcher can employ the same rules to achieve the same results. Thus, these aspects of content analysis assist to mitigate personal researcher bias.

Specifically, content analysis investigates the intensity of context units contained in texts. Context units can be specific words, sentences, characters, or concepts. The context unit in this paper is specific words, being the two terms and their related forms under analysis, namely "enable" and "transform". The content analysis process began with the development of a coding dictionary, which is a set of rules to ensure consistent and correct identification of the context units to be counted. The terminology analysis informed the development of the coding dictionary by providing the independent definitions of the terms under consideration. A coding dictionary provides guidance and ensures consistency, reliability, transparency, replicability, and objectivity. The content analysis produced a concept-count matrix or concept contingency table showing a multivariate frequency distribution, which facilitated the comparison of concepts and the identification of patterns.

\section{Sampling}

A basket of eight journals was selected for the content analysis. These eight journals were regarded as the top journals in the IS field by the Senior Scholars Consortium as presented on the website of the Association for Information Systems (Senior Scholars' Basket of Journals. 2011; Loeser, 2013). These journals, in alphabetical order, were the European Journal of Information Systems, Information Systems Journal, Information Systems Research, Journal of AIS, Journal of Information Technology, Journal of MIS, Journal of Strategic Information Systems, and MIS Quarterly.

These journals were searched manually for Green IS and related articles that were published between the dates 1 January 2010 and 30 September 2014, inclusive. 2010 was selected as the start year because this was the year when seminal calls for Green IS research appeared in MIS Quarterly (Melville, 2010; Watson et al., 2010). Appendix B details the discovered Green IS journal articles. 


\section{Coding Dictionary}

While there are many terminology debates around the definitions and boundaries of IS and Information Technology (IT), this paper follows the view that IT is a component of IS (Watson, Boudreau, Chen, \& Huber, 2008). In line with this view, IT focuses on the technological systems comprised of physical devices and associated software that are used to retrieve, transmit, process, and store data and information (Watson et al., 2008). In contrast, IS are the systems that emerge from the interaction between social systems comprised of people and processes and the aforementioned technological systems comprised of IT, in support of individual, organizational, or societal goals (Watson et al., 2010; Lee, 2004). Thus, in this paper, IS includes IT or IT is part of IS. Furthermore, Green IT is the application of ES throughout the IT lifecycle (Molla, Pittayachawan, \& Corbitt, 2009; Murugesan, 2008) with a focus on e-waste minimization and energy efficiency maximization (Watson et al., 2008). In contrast, Green IS address the extensive problem of overall environmental resource depletion and degradation (Watson et al., 2008). As such, Green IS encompass Green IT, since IT's environmental impact forms part of overall environmental resource depletion and degradation (Watson et al., 2010). Thus, in this paper, Green IS includes Green IT or Green IT is part of Green IS. In addition, the phrase "Green IS" was not used in the coding dictionary for reasons of coding simplicity. However, Green IS are defined as IS for environmental sustainability and this is the wording used to denote Green IS in the coding dictionary, which is presented in Appendix A.

\section{Findings and Discussion}

\section{Search Results}

In each discovered journal article, electronic searches were done using the keywords "enabl" and "transform". These searches were done in Atlas.ti (ATLAS.Ti. n.d.), which is qualitative research analysis software. Synonyms and antonyms of the search keywords were excluded from the study and may provide opportunities for further research. The searches were done on all sections of each article including the abstract section and titles, but excluding the keyword, references, and appendix sections. For each discovered keyword, the context of the discovered keyword was analyzed and assigned to one of the coding dictionary category codes using a best-fit interpretation by the researcher. Thereafter, Atlas.ti was used to produce the counts for the concept contingency table.

Table 3 is the concept contingency table showing the frequency of each coding dictionary category code per discovered journal article. The category codes with no frequencies in any of the discovered journals were omitted from Table 3 due to table size constraints, these category codes are NI-E-NE-I, NI-T-ES-I, NI-T-ES-S, IS-T-NE-I, NI-T-NE-I, IS-E-EDD-I, IS-E-EDD-S, NI-EEDD-I, NI-E-EDD-O, NI-NT-AE-I, and NI-NT-AE-S. 
Table 3: Concept contingency table showing the frequency of each category code per discovered journal article

\begin{tabular}{|c|c|c|c|c|c|c|c|c|c|c|c|c|c|c|c|c|c|c|c|c|c|c|}
\hline 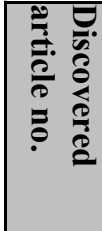 & 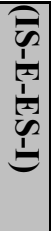 & $\begin{array}{l}a \\
0 \\
1 \\
1 \\
1 \\
1 \\
0 \\
0 \\
0 \\
0\end{array}$ & $\begin{array}{l}\bar{n} \\
1 \\
1 \\
1 \\
10 \\
10 \\
1 \\
0 \\
0\end{array}$ & $\begin{array}{l}\frac{2}{7} \\
\frac{1}{10} \\
1 \\
0 \\
0 \\
0 \\
0\end{array}$ & $\begin{array}{l}z \\
\frac{Z}{1} \\
0 \\
1 \\
1 \\
0 \\
0 \\
0 \\
0\end{array}$ & 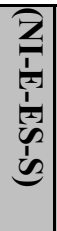 & $\begin{array}{l}\text { है } \\
1 \\
1 \\
1 \\
2 \\
2 \\
1 \\
\vdots\end{array}$ & $\begin{array}{l}\text { च } \\
1 \\
1 \\
1 \\
1 \\
2 \\
0 \\
0\end{array}$ & $\begin{array}{l}2 \\
\bar{w} \\
1 \\
1 \\
1 \\
2 \\
1 \\
0 \\
0\end{array}$ & 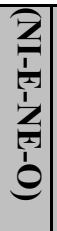 & $\begin{array}{l}z \\
z \\
\frac{1}{2} \\
1 \\
z \\
1 \\
1 \\
0 \\
0\end{array}$ & 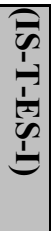 & $\begin{array}{l}\overrightarrow{0} \\
4 \\
1 \\
1 \\
1 \\
0 \\
1 \\
0\end{array}$ & 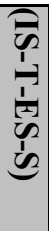 & $\begin{array}{l}2 \\
Z \\
T \\
+1 \\
1 \\
0 \\
0 \\
0\end{array}$ & 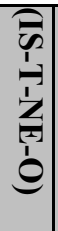 & $\begin{array}{l}\overline{7} \\
1 \\
\frac{1}{1} \\
z \\
-1 \\
1 \\
0\end{array}$ & 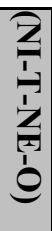 & $\begin{array}{l}\frac{2}{2} \\
\frac{1}{1} \\
\frac{1}{1} \\
0 \\
0 \\
0\end{array}$ & $\begin{array}{l}\text { चे } \\
\frac{1}{1} \\
\frac{1}{2} \\
\frac{1}{2} \\
0 \\
0 \\
0 \\
0\end{array}$ & 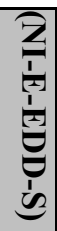 & 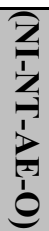 \\
\hline 1 & & 16 & & & 3 & & & 18 & & 7 & & & 2 & & & & & & & & & \\
\hline 2 & 4 & 2 & & 2 & & & & & & & & & 1 & & & & & & & & & \\
\hline 3 & & 1 & & & & & & 1 & & & & & & & & & & & & 2 & & \\
\hline 4 & & 32 & & & 1 & & & & & 2 & & & & & 1 & & & 1 & & & & \\
\hline 5 & 2 & & & & & & 6 & 3 & & & & & & & & & & & & & & \\
\hline 6 & & 9 & & & 1 & & & 17 & & 2 & & & 1 & & 2 & 2 & & & & & & \\
\hline 7 & 1 & & & & & & 3 & & & & & & 1 & & 1 & & & & & & & \\
\hline 8 & & 5 & & & 13 & 1 & & 16 & & 1 & & & 3 & & & 11 & & & & & & \\
\hline 9 & & 1 & & & & & & & & & & & 1 & & & & & & & & & \\
\hline 10 & & 1 & & 1 & 2 & & & & & 2 & & & & & 1 & & & 1 & 2 & & & \\
\hline 11 & & & & & & & & & & & & & & & & & & & 1 & & & \\
\hline 12 & & 5 & 1 & & & & & 4 & & 1 & & & 1 & & & 1 & & & & & & \\
\hline 13 & 3 & 14 & & & 1 & & & 2 & & & & & 1 & & 1 & 2 & 1 & & & & & \\
\hline 14 & & & 3 & & & 3 & & & & & 1 & & & 3 & 1 & & & & & & & \\
\hline 15 & 2 & 7 & 2 & & 1 & 11 & & & & & & & 1 & 1 & 33 & & & 1 & 1 & & 1 & 1 \\
\hline 16 & & 2 & & & & 1 & & 3 & 1 & 1 & & 3 & 1 & 1 & 11 & & 5 & & & & & \\
\hline 17 & & 27 & 1 & & 1 & & & 7 & & 3 & & & 15 & & 76 & 1 & & 2 & & & & \\
\hline 18 & & & & & & & & 4 & & & & & & & & & & & & & & \\
\hline 19 & 5 & & & & & & & & & & & & & & & & & & & & & \\
\hline Total & 17 & 167 & 7 & 3 & 23 & 16 & 9 & 75 & 1 & 19 & 1 & 3 & 37 & 5 & 127 & 17 & 6 & 5 & 4 & 2 & 1 & 1 \\
\hline
\end{tabular}

\section{Findings}

The analysis proceeded with a comparison of the category code frequencies to determine the usage of the terms "enable" and "transform" and their related forms in the Green IS literature. Figure 1 shows the three most prominent category codes. These are specifically IS providing the means for ES and related at the organizational level (IS-E-ES-O) with 167 occurrences or 30.6\% of all occurrences; specifically IS providing the means for an end other than ES at the organizational level (IS-E-NE-O) with 75 occurrences or $13.7 \%$ of all occurrences; and not specifically IS or not IS radically altering for ES and related at the organizational level (NI-T-ES-O) with 127 occurrences or $23.3 \%$ of all occurrences. These three category codes account for $67.6 \%$ of all occurrences. Thus, in the sampled literature, IS perform a prominent enabling role both for ES and for other ends at the organizational level. In addition, there are mostly non-IS that are transforming organizations for ES. 


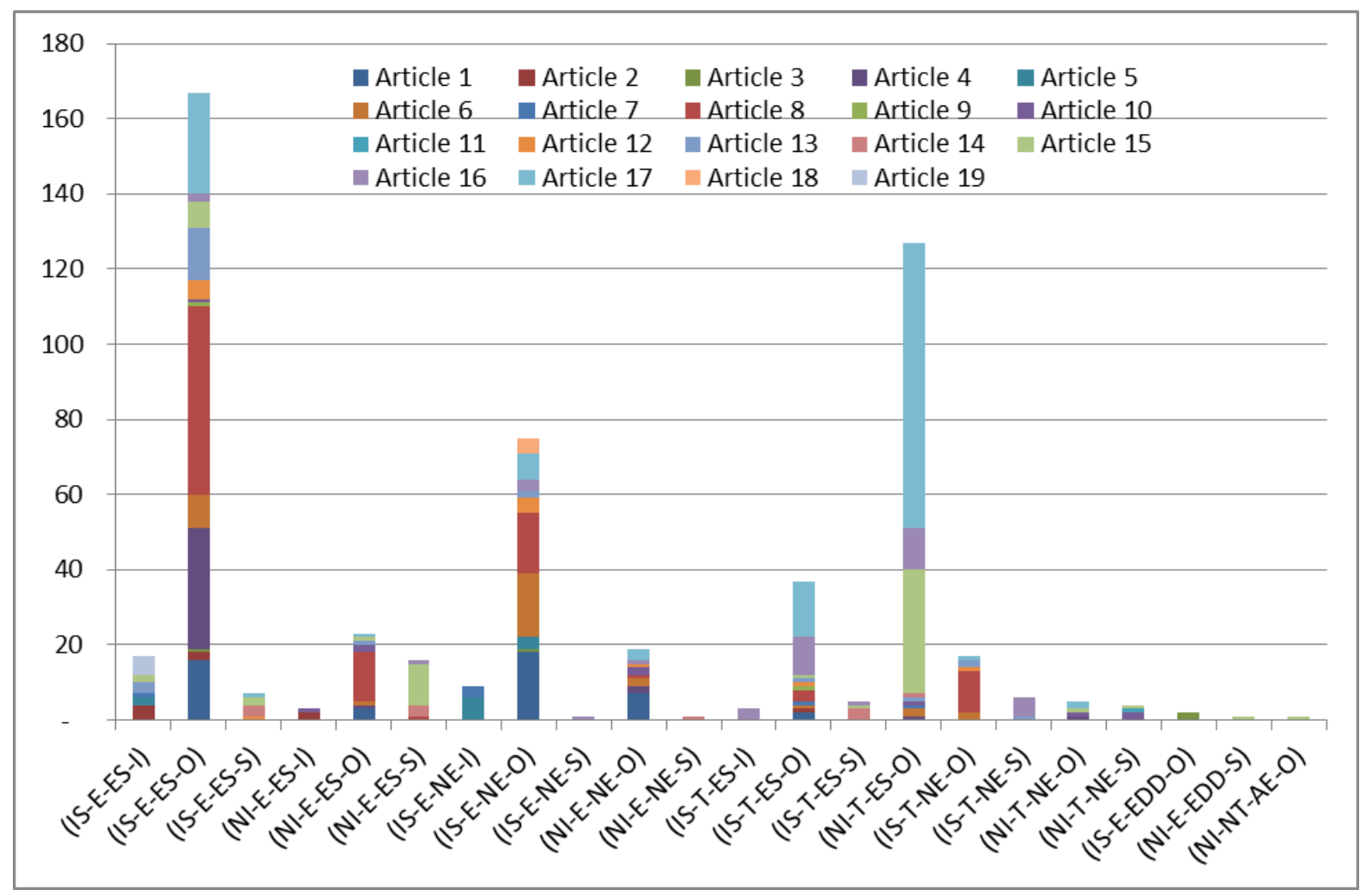

Figure 1: Frequency of each non-zero category code in total and per discovered journal article.

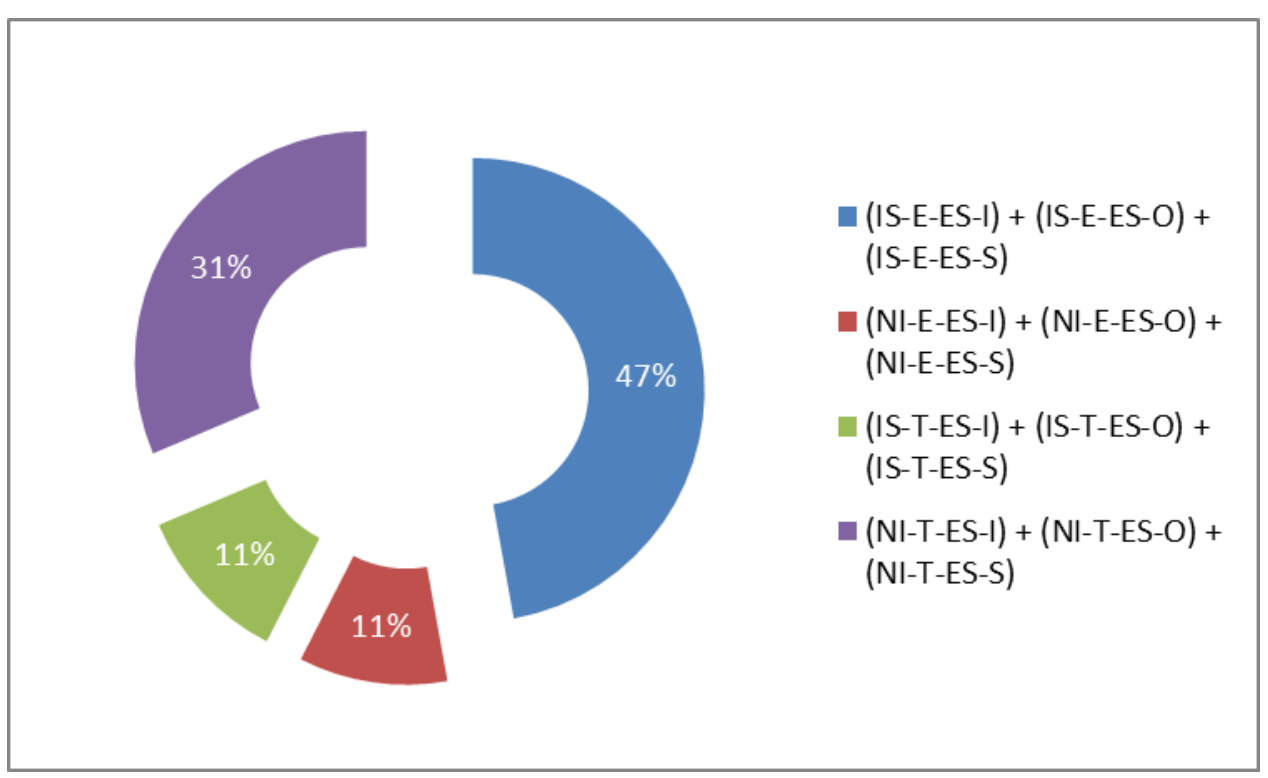

Figure 2: Relative frequency of IS and non-IS roles for ES at all levels across all articles.

In order to understand the roles of IS and non-IS specifically for ES, Figure 2 shows the relative frequency of IS enabling ES, non-IS enabling ES, IS transforming for ES, and non-IS transforming for ES at all level of analysis and across all articles. Similar to the depiction in Figure 1, Figure 2 shows that the role of IS enabling for ES is conspicuous with almost half of the all these 
occurrences. Thus, the role of IS enabling ES is again prominent. Furthermore, it is evident that there are almost three times more non-IS transforming for ES than IS transforming for ES.

For comparison and to understand the roles of both IS and non-IS for ends other than ES, Figure 3 shows relative frequency of IS enabling for an end other than ES, non-IS enabling for an end other than ES, IS transforming for an end other than ES, and non-IS transforming for an end other than ES at all level of analysis and across all articles. It is evident that IS enabling for ends other than ES account for almost two thirds of all these occurrences, while IS transforming for ends other than ES account for 17\%. This is almost a fourfold difference, which again depicts the prominence of the enabling role of IS when compared to the transforming role of IS, even in relation to ends other than ES.

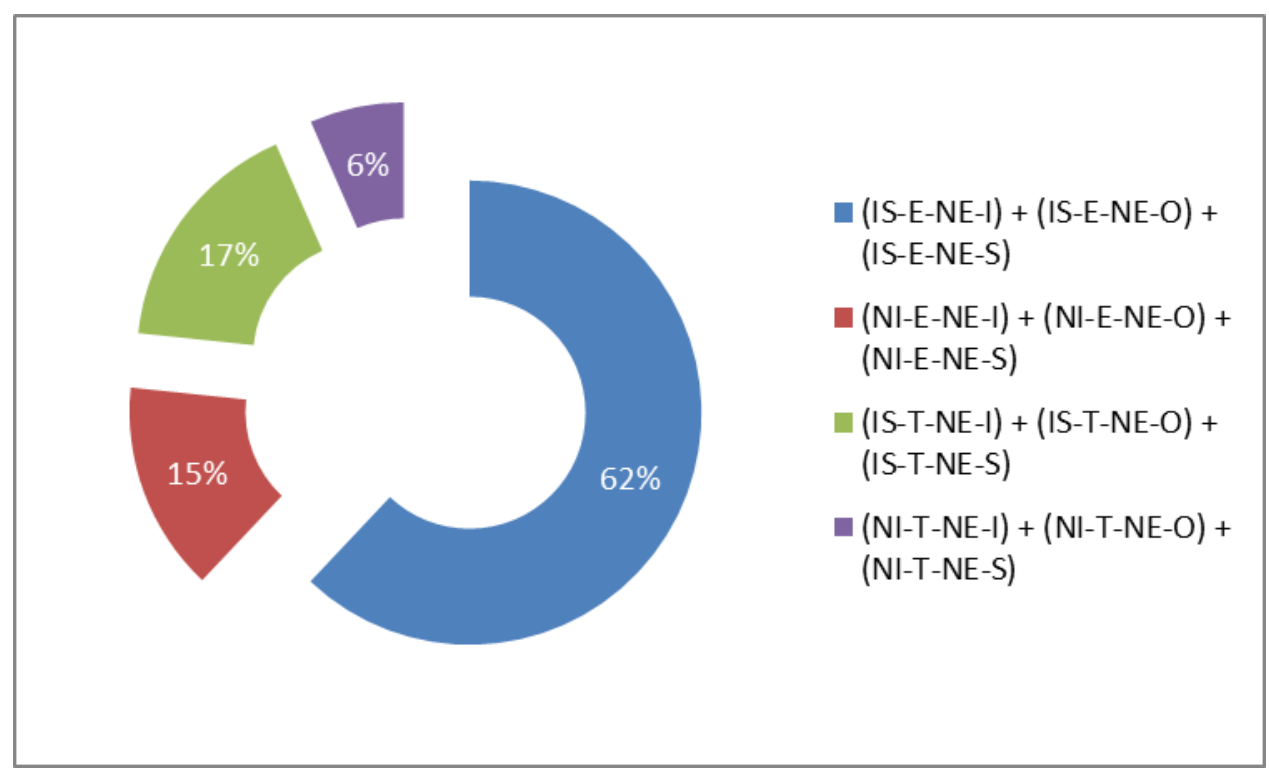

Figure 3: Relative frequency of IS non-IS roles for ends other than ES at all levels across all articles.

\section{Concluding Remarks}

\section{Research Problem, Objective, and Questions}

The research problem addressed in this paper is the ambiguity that exists in the usage of the terms "enable" and "transform" and their related forms in the Green IS literature. The paper has addressed this problem by defining these terms independently and using those independent meanings to content analyze their use. The result is the disambiguation of these terms.

Furthermore, the content analysis provided answers to the research questions. It was evident that the terms "enable" and "transform" and their related forms signify distinct roles. In terms of IS, the enabling role played for ES and for other ends was far more prominent than the transforming role. This revealed that IS play a predominantly enabling role, especially in relation to ES. Thus, Green IS are predominantly enabling in nature, based on the sampled Green IS literature.

This has consequences for Green IS research and practice. The calls for Green IS research to alter radically for ES are not being completely met, even though the urgent ES problems such as climate change require individuals, organizations, and society to change radically. However, there are significant non-IS transforming forces such as legislation and stakeholder pressure that are causing radical change. It may be useful for Green IS research to focus on enabling these non-IS 
transforming forces for ES, which is an equally important and vital role. Both roles can result in the same vital ES outcome. Nonetheless, where IS are able to transform for ES this is as important, but the aforementioned evidence suggests that this will occur less frequently. Indeed, based on the relative frequencies, the enabling role of Green IS provides more frequent ES returns. Thus, it may be preferable for Green IS research to focus on exposing the enabling capabilities of Green IS for optimal success in the multitudinous ES scenarios.

\section{Limitations and Future Research}

Interpreting the use contexts of each term was a subjective exercise with an inherent potential for bias, and, although the detailed coding dictionary rules aimed to mitigate this bias, there is the possibility that other researchers may obtain different results. However, the large difference in the usage of the terms "enable" and "transform" and their related forms suggest that with a low interpretation error rate the overall results will not change. Nonetheless, duplicating this research may be a useful avenue for further research.

Moreover, extending this research to all IS research domains, not just Green IS, and various time periods may provide insight into the roles that IS play in general, over time, and in their specialized domains. Indeed, exposing the nature and theory of these roles and how they can be actuated to solve problems is crucially important for researchers and practitioners.

\section{References}

ATLAS.Ti. (n.d.). Retrieved September 14, 2012, from http://www.atlasti.com/index.html

Bengtsson, F., \& Ågerfalk, P. J. (2011). Information technology as a change actant in sustainability innovation: Insights from Uppsala. Journal of Strategic Information Systems, 20(1), 96-112.

Benitez-Amado, J., \& Walczuch, R. M. (2012). Information technology, the organizational capability of proactive corporate environmental strategy and firm performance: A resource-based analysis. European Journal of Information Systems, 21(6), 664-679.

Berthon, P., \& Donnellan, B. (2011). Editorial: The greening of IT: Paradox or promise? Journal of Strategic Information Systems, 20(1), 3-5.

Bhattacherjee, A., \& Premkumar, G. (2004). Understanding changes in belief and attitude toward information technology usage: A theoretical model and longitudinal test. MIS Quarterly, 28(2), 229-254.

Bose, R., \& Luo, X. (2011). Integrative framework for assessing firms' potential to undertake green IT initiatives via virtualization - A theoretical perspective. Journal of Strategic Information Systems, 20(1), $38-54$.

Bryman, A., \& Bell, E. (2011). Business research methods (3rd ed.). New York, USA: Oxford University Press.

Butler, T. (2011). Compliance with institutional imperatives on environmental sustainability: Building theory on the role of green IS. Journal of Strategic Information Systems, 20(1), 6-26.

Ceci, F., \& Iubatti, D. (2012). Personal relationships and innovation diffusion in SME networks: A content analysis approach. Research Policy, 41(3), 565-579.

Corbett, J. (2013). Designing and using carbon management systems to promote ecologically responsible behaviors. Journal of the Association for Information Systems, 14(7), 339-378.

Dao, V., Langella, I., \& Carbo, J. (2011). From green to sustainability: Information technology and an integrated sustainability framework. Journal of Strategic Information Systems, 20(1), 63-79.

DesAutels, P., \& Berthon, P. (2011). The PC (polluting computer): Forever a tragedy of the commons? Journal of Strategic Information Systems, 20(1), 113-122.

Dictionary.Com. (n.d.). Retrieved July19, 2012, from http://dictionary.reference.com/ 
Elliot, S. (2011). Transdisciplinary perspectives on environmental sustainability: A resource base and framework for IT-enabled business transformation. MIS Quarterly, 35(1), 197-236.

Greene, J. C., \& Caracelli, V. J. (1997). Defining and describing the paradigm issue in mixed-method evaluation. In J. C. Greene, \& V. J. Caracelli (Eds.), Advances in mixed-method evaluation: The challenges and benefits of integrating diverse paradigms (New Directions for Evaluation, No. 74 ed., pp. 5-17). San Francisco: Jossey-Bass.

Henfridsson, O., \& Lind, M. (2014). Information systems strategizing, organizational sub-communities, and the emergence of a sustainability strategy. Journal of Strategic Information Systems, 23(1), 11-28.

Lee, A. S. (2004). Thinking about social theory and philosophy for information systems. In J. Mingers, \& L. Willcocks (Eds.), Social theory and philosophy for information systems (pp. 1-26). Chichester, UK: John Wiley \& Sons.

Loeser, F. (2013). Green IT and green IS: Definition of constructs and overview of current practices. Proceedings of the 19th Americas Conference on Information Systems (AMCIS), Chicago, Illinois, USA, 113.

Loock, C., Staake, T., \& Thiesse, F. (2013). Motivating energy-efficient behavior with green IS: An investigation of goal setting and the role of defaults. MIS Quarterly, 37(4), 1313-1332.

Lucas Jr., H. C., Agarwal, R., El Sawy, O. A., \& Weber, B. (2013). Impactful research on transformational information technology: An opportunity to inform new audiences. MIS Quarterly, 37(2), 371-382.

Malhotra, A., Melville, N. P., \& Watson, R. T. (2013). Spurring impactful research on information systems for environmental sustainability. MIS Quarterly, 37(4), 1265-1274.

Marett, K., Otondo, R. F., \& Taylor, G. S. (2013). Assessing the effects of benefits and institutional influences on the continued use of environmentally munificent bypass systems in long-haul trucking. MIS Quarterly, 37(4), 1301-1312.

Melville, N. P. (2010). Information systems innovation for environmental sustainability. MIS Quarterly, $34(1), 1-21$.

Molla, A., Pittayachawan, S., \& Corbitt, B. (2009). Green IT diffusion: An international comparison. Melbourne, Australia: School of Business Information Technology, RMIT University. Report No.1/2009. ISBN: 978-0-9805851-0-0.

Murugesan, S. (2008). Harnessing green IT: Principles and practices. IT Professional Magazine, 10(1), 2433.

Oxford Dictionaries. (n.d.). Retrieved August 18, 2014, from http://www.oxforddictionaries.com/

Pitt, L. F., Parent, M., Junglas, I., Chan, A., \& Spyropoulou, S. (2011). Integrating the smartphone into a sound environmental information systems strategy: Principles, practices and a research agenda. Journal of Strategic Information Systems, 20(1), 27-37.

Refseek.Com. (n.d.). Retrieved 23 January 2015, from http://www.refseek.com/directory/dictionaries.html.

Rocco, T. S., Bliss, L. A., Gallagher, S., \& Pérez-Prado, A. (2003). Taking the next step: Mixed methods research in organizational systems. Information Technology, Learning, and Performance Journal, 2l(1), 19-29.

Seidel, S., Recker, J., \& Vom Brocke, J. (2013). Sensemaking and sustainable practicing: Functional affordances of information systems in green transformations. MIS Quarterly, 37(4), 1275-1299.

Senior Scholars' Basket of Journals. (2011). Retrieved September 22, 2014, from http://aisnet.org/?SeniorScholarBasket

Siponen, M., \& Vance, A. (2010). Neutralization: New insights into the problem of employee information systems security policy violations. MIS Quarterly, 34(3), 487-502. 
Watson, R. T., Boudreau, M. C., \& Chen, A. J. (2010). Information systems and environmentally sustainable development: Energy informatics and new directions for the IS community. MIS Quarterly, 34(1), 23-38.

Watson, R. T., Boudreau, M. C., Chen, A. J., \& Huber, M. H. (2008). Green IS: Building sustainable business practices. In R. T. Watson (Ed.), Information systems (pp. 1-17). Athens, GA: Global Text Project.

Watson, R. T., Boudreau, M., Chen, A. J., \& Sepúlveda, H. H. (2011). Green projects: An information drives analysis of four cases. Journal of Strategic Information Systems, 20(1), 55-62.

Zhang, H., Liu, L., \& Li, T. (2011). Designing IT systems according to environmental settings: A strategic analysis framework. Journal of Strategic Information Systems, 20(1), 80-95.

Appendix A

\begin{tabular}{|c|c|c|}
\hline \multicolumn{3}{|c|}{ Table A. 1: Coding dictionary } \\
\hline KEYWORD & CATEGORY CODE CRITERIA & $\begin{array}{l}\text { CATEGORY } \\
\text { CODE }\end{array}$ \\
\hline enabl & $\begin{array}{l}\text { There is positive outcome + Specifically IS providing the means for ES and } \\
\text { related + Individual level of analysis }\end{array}$ & IS-E-ES-I \\
\hline enabl & $\begin{array}{l}\text { There is positive outcome + Specifically IS providing the means for ES and } \\
\text { related + Organizational level of analysis }\end{array}$ & IS-E-ES-O \\
\hline enabl & $\begin{array}{l}\text { There is positive outcome + Specifically IS providing the means for ES and } \\
\text { related + Societal level of analysis }\end{array}$ & IS-E-ES-S \\
\hline enabl & $\begin{array}{l}\text { There is positive outcome + Not specifically IS or not IS providing the means } \\
\text { for ES and related + Individual level of analysis }\end{array}$ & NI-E-ES-I \\
\hline enabl & $\begin{array}{l}\text { There is positive outcome + Not specifically IS or not IS providing the means } \\
\text { for ES and related +Organizational level of analysis }\end{array}$ & NI-E-ES-O \\
\hline enabl & $\begin{array}{l}\text { There is positive outcome + Not specifically IS or not IS providing the means } \\
\text { for ES and related + Societal level of analysis }\end{array}$ & NI-E-ES-S \\
\hline enabl & $\begin{array}{l}\text { There is positive outcome }+ \text { Specifically IS providing the means for an end } \\
\text { other than ES + Individual level of analysis }\end{array}$ & IS-E-NE-I \\
\hline enabl & $\begin{array}{l}\text { There is positive outcome }+ \text { Specifically IS providing the means for an end } \\
\text { other than ES + Organizational level of analysis }\end{array}$ & IS-E-NE-O \\
\hline enabl & $\begin{array}{l}\text { There is positive outcome }+ \text { Specifically IS providing the means for an end } \\
\text { other than ES + Societal level of analysis }\end{array}$ & IS-E-NE-S \\
\hline enabl & $\begin{array}{l}\text { There is positive outcome + Not specifically IS or not IS providing the means } \\
\text { for an end other than ES + Individual level of analysis }\end{array}$ & NI-E-NE-I \\
\hline enabl & $\begin{array}{l}\text { There is positive outcome + Not specifically IS or not IS providing the means } \\
\text { for an end other than ES + Organizational level of analysis }\end{array}$ & NI-E-NE-O \\
\hline enabl & $\begin{array}{l}\text { There is positive outcome + Not specifically IS or not IS providing the means } \\
\text { for an end other than ES + Societal level of analysis }\end{array}$ & NI-E-NE-S \\
\hline
\end{tabular}




\begin{tabular}{|c|c|c|}
\hline \multicolumn{3}{|c|}{ Table A. 1: Coding dictionary } \\
\hline KEYWORD & CATEGORY CODE CRITERIA & $\begin{array}{l}\text { CATEGORY } \\
\text { CODE }\end{array}$ \\
\hline transform & $\begin{array}{l}\text { There is positive outcome + Specifically IS radically altering for ES and relat- } \\
\text { ed + Individual level of analysis }\end{array}$ & IS-T-ES-I \\
\hline transform & $\begin{array}{l}\text { There is positive outcome + Specifically IS radically altering for ES and relat- } \\
\text { ed +Organizational level of analysis }\end{array}$ & IS-T-ES-O \\
\hline transform & $\begin{array}{l}\text { There is positive outcome + Specifically IS radically altering for ES and relat- } \\
\text { ed + Societal level of analysis }\end{array}$ & IS-T-ES-S \\
\hline transform & $\begin{array}{l}\text { There is positive outcome + Not specifically IS or not IS radically altering for } \\
\text { ES and related + Individual level of analysis }\end{array}$ & NI-T-ES-I \\
\hline transform & $\begin{array}{l}\text { There is positive outcome + Not specifically IS or not IS radically altering for } \\
\text { ES and related + Organizational level of analysis }\end{array}$ & NI-T-ES-O \\
\hline transform & $\begin{array}{l}\text { There is positive outcome + Not specifically IS or not IS radically altering for } \\
\text { ES and related + Societal level of analysis }\end{array}$ & NI-T-ES-S \\
\hline transform & $\begin{array}{l}\text { There is positive outcome + Specifically IS radically altering for an end other } \\
\text { than ES + Individual level of analysis }\end{array}$ & IS-T-NE-I \\
\hline transform & $\begin{array}{l}\text { There is positive outcome + Specifically IS radically altering for an end other } \\
\text { than ES + Organizational level of analysis }\end{array}$ & IS-T-NE-O \\
\hline transform & $\begin{array}{l}\text { There is positive outcome + Specifically IS radically altering for an end other } \\
\text { than ES + Societal level of analysis }\end{array}$ & IS-T-NE-S \\
\hline transform & $\begin{array}{l}\text { There is positive outcome + Not specifically IS or not IS radically altering for } \\
\text { an end other than ES + Individual level of analysis }\end{array}$ & NI-T-NE-I \\
\hline transform & $\begin{array}{l}\text { There is positive outcome + Not specifically IS or not IS radically altering for } \\
\text { an end other than ES + Organizational level of analysis }\end{array}$ & NI-T-NE-O \\
\hline transform & $\begin{array}{l}\text { There is positive outcome + Not specifically IS or not IS radically altering for } \\
\text { an end other than ES + Societal level of analysis }\end{array}$ & NI-T-NE-S \\
\hline enabl & $\begin{array}{l}\text { There is negative outcome + Specifically IS providing the means for envi- } \\
\text { ronmental depletion and degradation + Individual level of analysis }\end{array}$ & IS-E-EDD-I \\
\hline enabl & $\begin{array}{l}\text { There is negative outcome + Specifically IS providing the means for envi- } \\
\text { ronmental depletion and degradation + Organizational level of analysis }\end{array}$ & IS-E-EDD-O \\
\hline enabl & $\begin{array}{l}\text { There is negative outcome + Specifically IS providing the means for envi- } \\
\text { ronmental depletion and degradation }+ \text { Societal level of analysis }\end{array}$ & IS-E-EDD-S \\
\hline enabl & $\begin{array}{l}\text { There is negative outcome + Not specifically IS or not IS providing the means } \\
\text { for environmental depletion and degradation + Individual level of analysis }\end{array}$ & NI-E-EDD-I \\
\hline enabl & $\begin{array}{l}\text { There is negative outcome + Not specifically IS or not IS providing the means } \\
\text { for environmental depletion and degradation + Organizational level of analysis }\end{array}$ & NI-E-EDD-O \\
\hline enabl & $\begin{array}{l}\text { There is negative outcome + Not specifically IS or not IS providing the means } \\
\text { for environmental depletion and degradation + Societal level of analysis }\end{array}$ & NI-E-EDD-S \\
\hline
\end{tabular}




\begin{tabular}{|l|l|l|}
\hline \multicolumn{3}{|c|}{ Table A. 1: Coding dictionary } \\
\hline $\begin{array}{c}\text { KEYWORD } \\
\text { SEARCH }\end{array}$ & \multicolumn{1}{|c|}{ CATEGORY CODE CRITERIA } & $\begin{array}{c}\text { CATEGORY } \\
\text { CODE }\end{array}$ \\
\hline transform & $\begin{array}{l}\text { There is negative outcome + Not specifically IS or not IS NOT radically alter- NI-NT-AE-I } \\
\text { ing for any end + Individual level of analysis }\end{array}$ & N-N \\
\hline transform & $\begin{array}{l}\text { There is negative outcome + Not specifically IS or not IS NOT radically alter- } \\
\text { ing for any end + Organizational level of analysis }\end{array}$ & NI-NT-AE-O \\
\hline transform & $\begin{array}{l}\text { There is negative outcome + Not specifically IS or not IS NOT radically alter- } \\
\text { ing for any end + Societal level of analysis }\end{array}$ & NI-NT-AE-S \\
\hline
\end{tabular}

\section{Appendix B}

Table B. 1: Discovered journal articles (grouped by journal title and article publication date) in the senior scholars' basket of journals

\begin{tabular}{|c|c|c|c|c|}
\hline NO. & AUTHOR/S & TITLE & $\begin{array}{l}\text { YEAR, VOL., } \\
\text { ISSUE }\end{array}$ & JOURNAL \\
\hline 1 & $\begin{array}{l}\text { (Benitez-Amado \& } \\
\text { Walczuch, 2012) }\end{array}$ & $\begin{array}{l}\text { Information technology, the organiza- } \\
\text { tional capability of proactive corporate } \\
\text { environmental strategy and firm perfor- } \\
\text { mance: A resource-based analysis }\end{array}$ & $\begin{array}{l}\text { Nov 2012; Vol. } \\
21(6)\end{array}$ & $\begin{array}{l}\text { European Journal of } \\
\text { Information Systems }\end{array}$ \\
\hline 2 & (Corbett, 2013) & $\begin{array}{l}\text { Designing and using carbon manage- } \\
\text { ment systems to promote ecologically } \\
\text { responsible behaviors }\end{array}$ & $\begin{array}{l}\text { Jul2013, Vol. } \\
14 \text { Issue } 7\end{array}$ & $\begin{array}{l}\text { Journal of the Asso- } \\
\text { ciation for Infor- } \\
\text { mation Systems }\end{array}$ \\
\hline 3 & $\begin{array}{l}\text { (Berthon \& Donnel- } \\
\text { lan, 2011) }\end{array}$ & $\begin{array}{l}\text { Editorial: The greening of IT: Paradox or } \\
\text { promise? }\end{array}$ & $\begin{array}{l}\text { March 2011, } \\
\text { Volume 20, } \\
\text { Issue 1 }\end{array}$ & $\begin{array}{l}\text { Journal of Strategic } \\
\text { Information Systems }\end{array}$ \\
\hline 4 & (Butler, 2011) & $\begin{array}{l}\text { Compliance with institutional impera- } \\
\text { tives on environmental sustainability: } \\
\text { Building theory on the role of Green IS }\end{array}$ & $\begin{array}{l}\text { March 2011, } \\
\text { Volume 20, } \\
\text { Issue } 1\end{array}$ & $\begin{array}{l}\text { Journal of Strategic } \\
\text { Information Systems }\end{array}$ \\
\hline 5 & $\begin{array}{l}\text { (Pitt, Parent, Jun- } \\
\text { glas, Chan, \& Spy- } \\
\text { ropoulou, 2011) }\end{array}$ & $\begin{array}{l}\text { Integrating the smartphone into a sound } \\
\text { environmental information systems } \\
\text { strategy: Principles, practices and a re- } \\
\text { search agenda }\end{array}$ & $\begin{array}{l}\text { March 2011, } \\
\text { Volume 20, } \\
\text { Issue } 1\end{array}$ & $\begin{array}{l}\text { Journal of Strategic } \\
\text { Information Systems }\end{array}$ \\
\hline 6 & (Bose \& Luo, 2011) & $\begin{array}{l}\text { Integrative framework for assessing } \\
\text { firms' potential to undertake Green IT } \\
\text { initiatives via virtualization - A theoreti- } \\
\text { cal perspective }\end{array}$ & $\begin{array}{l}\text { March 2011, } \\
\text { Volume 20, } \\
\text { Issue } 1\end{array}$ & $\begin{array}{l}\text { Journal of Strategic } \\
\text { Information Systems }\end{array}$ \\
\hline 7 & $\begin{array}{l}\text { (Watson, Boudreau, } \\
\text { Chen, \& Sepúlveda, } \\
\text { 2011) }\end{array}$ & $\begin{array}{l}\text { Green projects: An information drives } \\
\text { analysis of four cases }\end{array}$ & $\begin{array}{l}\text { March 2011, } \\
\text { Volume 20, } \\
\text { Issue 1 }\end{array}$ & $\begin{array}{l}\text { Journal of Strategic } \\
\text { Information Systems }\end{array}$ \\
\hline 8 & $\begin{array}{l}\text { (Dao, Langella, \& } \\
\text { Carbo, 2011) }\end{array}$ & $\begin{array}{l}\text { From green to sustainability: Infor- } \\
\text { mation technology and an integrated } \\
\text { sustainability framework }\end{array}$ & $\begin{array}{l}\text { March 2011, } \\
\text { Volume 20, } \\
\text { Issue } 1\end{array}$ & $\begin{array}{l}\text { Journal of Strategic } \\
\text { Information Systems }\end{array}$ \\
\hline
\end{tabular}


Table B. 1: Discovered journal articles (grouped by journal title and article publication date) in the senior scholars' basket of journals

\begin{tabular}{|c|c|c|c|c|}
\hline NO. & AUTHOR/S & TITLE & $\begin{array}{l}\text { YEAR, VOL., } \\
\text { ISSUE }\end{array}$ & JOURNAL \\
\hline 9 & $\begin{array}{l}\text { (Zhang, Liu, \& Li, } \\
\text { 2011) }\end{array}$ & $\begin{array}{l}\text { Designing IT systems according to envi- } \\
\text { ronmental settings: A strategic analysis } \\
\text { framework }\end{array}$ & $\begin{array}{l}\text { March 2011, } \\
\text { Volume 20, } \\
\text { Issue 1 }\end{array}$ & $\begin{array}{l}\text { Journal of Strategic } \\
\text { Information Systems }\end{array}$ \\
\hline 10 & $\begin{array}{l}\text { (Bengtsson \& Åger- } \\
\text { falk, 2011) }\end{array}$ & $\begin{array}{l}\text { Information technology as a change act- } \\
\text { ant in sustainability innovation: Insights } \\
\text { from Uppsala }\end{array}$ & $\begin{array}{l}\text { March 2011, } \\
\text { Volume 20, } \\
\text { Issue } 1\end{array}$ & $\begin{array}{l}\text { Journal of Strategic } \\
\text { Information Systems }\end{array}$ \\
\hline 11 & $\begin{array}{l}\text { (DesAutels \& } \\
\text { Berthon, 2011) }\end{array}$ & $\begin{array}{l}\text { The PC (polluting computer): Forever a } \\
\text { tragedy of the commons? }\end{array}$ & $\begin{array}{l}\text { March 2011, } \\
\text { Volume 20, } \\
\text { Issue } 1\end{array}$ & $\begin{array}{l}\text { Journal of Strategic } \\
\text { Information Systems }\end{array}$ \\
\hline 12 & $\begin{array}{l}\text { (Henfridsson \& } \\
\text { Lind, 2014) }\end{array}$ & $\begin{array}{l}\text { Information systems strategizing, organ- } \\
\text { izational sub-communities, and the } \\
\text { emergence of a sustainability strategy }\end{array}$ & $\begin{array}{l}\text { March 2014, } \\
\text { Volume 23, } \\
\text { Issue } 1\end{array}$ & $\begin{array}{l}\text { Journal of Strategic } \\
\text { Information Systems }\end{array}$ \\
\hline 13 & (Melville, 2010) & $\begin{array}{l}\text { Information systems innovation for envi- } \\
\text { ronmental sustainability }\end{array}$ & $\begin{array}{l}\text { Mar2010, Vol. } \\
34 \text { Issue } 1\end{array}$ & MIS Quarterly \\
\hline 14 & (Watson et al., 2010) & $\begin{array}{l}\text { Information systems and environmental- } \\
\text { ly sustainable development: Energy in- } \\
\text { formatics and new directions for the IS } \\
\text { community }\end{array}$ & $\begin{array}{l}\text { Mar2010, Vol. } \\
34 \text { Issue } 1\end{array}$ & MIS Quarterly \\
\hline 15 & (Elliot, 2011) & $\begin{array}{l}\text { Transdisciplinary perspectives on envi- } \\
\text { ronmental sustainability: A resource } \\
\text { base and framework for IT-enabled } \\
\text { business transformation }\end{array}$ & $\begin{array}{l}\text { Mar2011, Vol. } \\
35 \text { Issue } 1\end{array}$ & MIS Quarterly \\
\hline 16 & $\begin{array}{l}\text { (Malhotra et al., } \\
\text { 2013) }\end{array}$ & $\begin{array}{l}\text { Spurring impactful research on infor- } \\
\text { mation systems for environmental sus- } \\
\text { tainability }\end{array}$ & $\begin{array}{l}\text { Dec2013, Vol. } \\
37 \text { Issue } 4\end{array}$ & MIS Quarterly \\
\hline 17 & (Seidel et al., 2013) & $\begin{array}{l}\text { Sensemaking and sustainable practicing: } \\
\text { Functional affordances of information } \\
\text { systems in green transformations }\end{array}$ & $\begin{array}{l}\text { Dec2013, Vol. } \\
37 \text { Issue } 4\end{array}$ & MIS Quarterly \\
\hline 18 & $\begin{array}{l}\text { (Marett, Otondo, \& } \\
\text { Taylor, 2013) }\end{array}$ & $\begin{array}{l}\text { Assessing the effects of benefits and } \\
\text { institutional influences on the continued } \\
\text { use of environmentally munificent by- } \\
\text { pass systems in long-haul trucking }\end{array}$ & $\begin{array}{l}\text { Dec2013, Vol. } \\
37 \text { Issue } 4\end{array}$ & MIS Quarterly \\
\hline 19 & $\begin{array}{l}\text { (Loock, Staake, \& } \\
\text { Thiesse, 2013) }\end{array}$ & $\begin{array}{l}\text { Motivating energy-efficient behavior } \\
\text { with Green IS: An investigation of goal } \\
\text { setting and the role of defaults }\end{array}$ & $\begin{array}{l}\text { Dec2013, Vol. } \\
37 \text { Issue } 4\end{array}$ & MIS Quarterly \\
\hline
\end{tabular}




\section{Biographies}

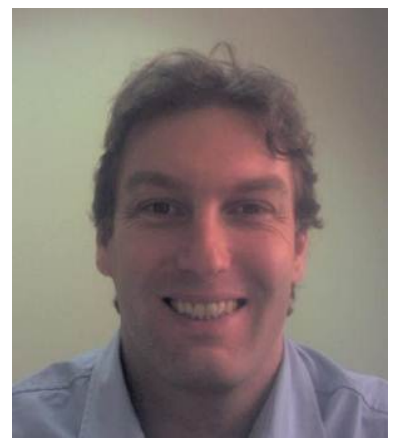

Grant R. Howard is a Ph.D candidate and a Senior Lecturer in Information Systems at the School of Computing, University of South Africa (UNISA). His research focuses on Information Systems in the domain of organizational, environmental sustainability. He has authored and presented several papers on this topic.

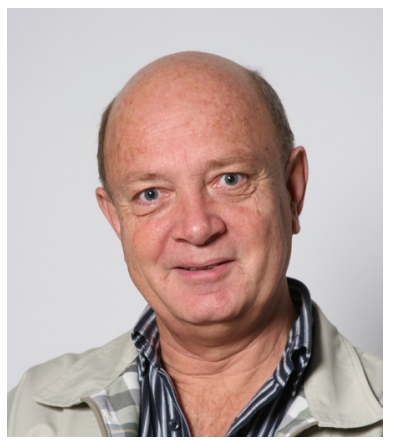

Sam Lubbe, Ph.D., is a research professor at Zululand University in the Department of Business Management. He teaches research methodologies and specializes in supervising honours, masters and doctoral students. He has published widely in scholarly journals, and attended and delivered many conference papers. He has edited three textbooks in Information Systems and authored a fourth.

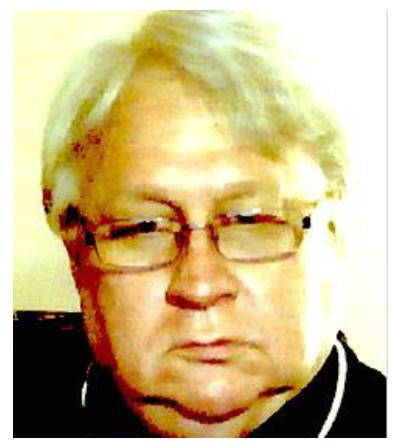

Rembrandt Klopper, Ph.D., is an interdisciplinary scholar publishing the results of research focusing on aspects of research methodology, informatics, communication science and cognitive science. He is a regular participant at international conferences on research methodology and informatics. In cognitive science he has written a number of papers on the central role of metaphor in human thinking. He co-supervises masters and doctoral students at several South African universities and is a special issues editor of the South African interdisciplinary scholarly journal, Alternation. 